\title{
PHYSICAL-FORCE CHARTISM: THE COTTON DISTRICT AND THE CHARTIST CRISIS OF $1839^{*}$
}

There is a real need to integrate local and national approaches to the study of Chartism. The inadequacies of the pioneering studies of the national movement certainly revealed the need to return to the local roots of the movement. ${ }^{1}$ However, the pattern of local studies largely established by the important volume of Chartist Studies edited by Asa Briggs has had some unfortunate consequences. ${ }^{2}$ The attempt to provide a comprehensive account of Chartism in a given locality, and cover the entire period from 1838 to 1848 , has often precluded extended examination of key issues. Such matters as the relationship between Chartism and other forms of popular protest, Chartist ideology and tactics, the relationship between the Chartists and the middle class, and the whole cultural and organisational dimension of Chartism have only recently begun to receive detailed analysis. ${ }^{3}$ There has been a marked tendency for one of the most remarkable aspects of Chartism, the extent to which diverse localities were united in a national movement, to be obscured. Indeed it is evident that many historians returned to the local roots of Chartism without adequate assessments of Chartist ideology, tactics, national organisation and national leadership. Some important recent work has done much to enhance our understanding of such matters. ${ }^{4} \mathrm{~A}$ more meaningful assessment of how events in the localities interacted with the national movement is now possible.

* I am grateful for the valuable comments of Dr I. J. Prothero and Mrs Dorothy Thompson on an early draft of this article. All dates cited refer to the year 1839 , unless otherwise specified.

${ }^{1}$ M. Hovell, The Chartist Movement, 3rd ed. (Manchester, 1966); J. West. History of the Chartist Movement (London, 1920).

2 Chartist Studies, ed. by A. Briggs (London, 1959).

${ }^{3}$ For a collection of studies, explicitly seeking to use local evidence to illuminate specific themes of national importance, see The Chartist Experience: Studies in Working-Class Radicalism and Culture, 1830-60, ed. by J. Epstein and D. Thompson (London, 1982). 4 I. J. Prothero, "William Benbow and the Concept of the General Strike", in: Past \& Present, No 63 (1974); id., Artisans and Politics in Early Nineteenth-Century London 
It is also a curious phenomenon that the local studies of Chartism, which seemed to be reaching epidemic proportions at one stage, almost completely neglected Lancashire. For, even when due attention is given to other regions, it remains clear that the cotton district, together with industrial Yorkshire, provided the real heart of the movement. Moreover, it remains the case that when due consideration has been given to neglected social and cultural aspects of Chartism, it is still the central point that it was a mass, working-class movement actually challenging for political power, which made the movement so significant in the first place. Almost certainly the most vigorous Chartist campaign, and certainly the occasion when most extravagant expectations were aroused, was in 1839. Chartism never fully recaptured the excited atmosphere and liberating exhilaration created by the widespread belief in the possibilities of success that existed in that year. The realisation of the power of the State and strength of opposing forces produced by the defeats of 1839 cast a shadow over subsequent Chartist campaigns.

This study examines the role of a particularly important and militant area, the cotton district, in the climax of that first great Chartist campaign. ${ }^{5}$ It attempts to provide an assessment of the adequacy of Chartist tactics, the degree of popular commitment to confrontational strategies, and the extent of arming. It examines the interaction between the local and national movements, and between the Chartists and the authorities, and reveals the vital importance of the collapse of Chartist plans for a general strike in the failure of the 1839 campaign. It is therefore concerned with a key episode in the development of mainstream popular politics. But it should not be seen as a retreat from the current concerns of social history to an older form of labour history, with a focus on more narrowly political chronology and upon the institutional development of the labour movement, rather than the wider social history of the working class. One consequence of the increasingly apparent collapse of the labour-aristocracy thesis in its most ambitious formulation, as a near-total, social and economic explanation of working-class political quiescence in mid-Victorian Britain, is a realisation that more attention needs to be paid to relatively autonomous political

(Folkestone, 1979); T. M. Parssinen, "Association, Convention and Anti-Parliament in British Radical Politics, 1771-1848", in: English Historical Review, LXXXVIII (1973); J. C. Beichem, "Henry Hunt and the Evolution of the Mass Platform", ibid., XCIII (1978); J. Epstein, The Lion of Freedom: Feargus O'Connor and the Chartist Movement, 1832-1842 (London, 1982); and G. Stedman Jones, "The Language of Chartism", in: The Chartist Experience.

5 The main focus is on the Southern, much larger part of the cotton district in South-East Lancashire and North-East Cheshire, which was more militant and active in 1839 than North Lancashire. 
developments. These certainly include the limitations of the ideology and tactics of the earlier-nineteenth-century radical movement, and the crucial role played by the State. From this perspective it is evident that the political events of 1839 made a very deep imprint indeed on the subsequent development of the working class in nineteenth-century Britain.

\section{Chartism in the cotton district, 1838-39}

So many of the most crucial aspects of Chartism in the cotton district were recognised by the visiting radical, Henry Vincent, that his private assessment is worth quoting at length.

One feeling prevails in every town - or rather I should say two feelings - the first a general and almost universal radical opinion - resolved to aid in one more attempt to obtain by peaceful means a full recognition of the Universal Rights of the people - and second an apparent fixed resolution to appeal to arms should this last moral effort fail - I regret the prevalence of opinions of a physical nature - but we cannot wonder at them. Ever since the year 1818 - the Yorkshire and Lancashire people have been peacefully struggling for Universal Suffrage. They were the only two counties in which the principle existed to any extent and the choicest spirits have become almost worn out by their continuous exertions. - However they will nobly do their duty now - They see now, for the first time, a corresponding energy in other parts of the nation. You have no idea of the intensity of radical opinions here. You have an idea from the numerous public house signs - full length portraits of Hunt - holding in his hand scrawls [sic] containing the words Universal Suffrage, Annual Parliaments, and the Ballot. Paine and Cobbett also figure occasionally - Stephens the Clergyman of Ashton openly preaches from his pulpit the necessity of the people being armed to prepare for the worst $-{ }^{6}$

Vincent fully recognised the importance of the prior strength of mass, albeit often latent, support for radicalism, which was deeply ingrained into the local working-class culture, and the existing structure of local radical leadership. ${ }^{7} \mathrm{He}$ also observed the prevalence of the notion that this was to be the last petitioning campaign. This belief gave the movement of 1838-39 so much of its apocalyptic fervour. He further understood the vital point that it was the perceived possibilities of success, created by the prospect of a truly national movement, which gave the crucial impetus to mass mobilisation. Finally, he of course noted the early militant tone and the early emphasis on arming.

Shortly afterwards, the huge "South Lancashire Demonstration", held

6 Vincent to Minikin, 26 August 1838, Minikin-Vincent Papers, Labour Party Library.

7 See R.A. Sykes, "Popular Politics and Trade Unionism in South-East Lancashire, 1829-42" (unpublished Ph.D., Manchester, 1982), ch. 9, for an examination of radicalism in the 1830 's. 
on Kersal Moor just outside Manchester, publicly signalled the arrival of Chartism as a coherent mass movement. ${ }^{8}$ Local Chartism was given a momentum of its own. This was developed during the subsequent mass meetings held in each town. Like Kersal Moor, these were held to adopt the Charter and elect delegates to the Convention. Because of the problem of victimisation they were held at night, and in the darkening winter nights that meant by torchlight. ${ }^{9}$ The radicals immediately began to exploit the obvious potential for generating working-class self-confidence and alarming the authorities. All these meetings were large, and the speeches more violent than ever before. They were also accompanied by defiant processions, like the one at Hyde, where 10,000 marched around the township "with torches burning, bands playing, clarions sounding and the cries of Death or our Rights", all with accompanying small arms fire. ${ }^{10}$

In December the Government proclamation against the torchlight meetings, which the cotton district had pioneered, and the arrest of Stephens brought this initial phase of Chartism to a close. ${ }^{11}$ The development of Chartism was now becoming inextricably bound up with action by the authorities. The cotton district was spearheading developments in an increasingly confrontational situation. In early 1839 all awaited developments at the Convention, but as the time for the presentation of the National Petition drew nearer, the focus of attention moved back to the localities. For the expected rejection of the petition would necessitate resorting to the "ulterior measures", designed to force the concession of the Charter. In May the atmosphere became markedly more threatening. In the cotton district there were the first arrests since that of Stephens, the ostentatious build-up of troops and the second great Kersal Moor demonstration, which endorsed all the ulterior measures contained in the Convention's Manifesto. ${ }^{12}$ An acute crisis developed as an increasingly militant Chartist movement moved towards direct action, at the same time as the Government moved towards more active repression. The compo-

${ }^{8}$ Manchester Guardian, 26 September 1838; Manchester and Salford Advertiser, 29 September 1838 .

9 There were torchlight meetings at Stockport, Ramsbottom, Boiton, Rochdale, Oldham, Leigh, Hyde and Bury, see especially Manchester and Salford Advertiser, 6 and 20 October, 3, 10 and 17 November, 15 December 1838; Northern Star, same dates; reports in Treasury Solicitor's Papers 11/815-16. Public Record Office, London.

10 Hyde Magistrates to Russell, 16 November 1838, Home Office Papers (hereafter HO) 40/38, Public Record Office; Treasury Solicitor's Papers 11/815/2683 and 2687.

1 See Phillipps to all local magistrates, 15 December 1838, HO 41/13; id. to the Leigh magistrates, 24 December 1838 , ibid., for the go-ahead to arrest Stephens.

12 Manchester Guardian, 8 and 22 May; Manchester and Salford Advertiser, 11 and 25 May. 
nents of that crisis, the "physical-force Chartism" of 1839 , the arming, and the response of the authorities need to be considered before moving on to examine the climax of the Lancashire campaign in the summer.

\section{Physical-force Chartism}

Neither in Lancashire, nor anywhere else, can Chartist policies or leaders be neatly divided into separate and static moral-force and physical-force categories. ${ }^{13}$ Instead the differences are best conceptualised as varying points on a continuum. This began with the position of those favouring only "moral" and wholly peaceful persuasion under any circumstances, and ended with those aiming at aggressive insurrectionary action. In between were many different positions about how threatening it was believed the movement needed to become in order to achieve success, and at what point Government repression justified violent resistance. In such a continuum, as in that most popular Chartist slogan of 1839 , "peaceably if we may, forcibly if we must", moral and physical force were seen as aspects of the same policy of threatening, but essentially constitutional agitation. Initially very few Chartists were prepared to countenance conspiratorial insurrectionary preparations, but also very few were prepared to renounce the use of physical force of some kind under all circumstances. Mainstream Chartist opinion increasingly moved towards more militant strategies during the course of 1838-39. For the failure of peaceful methods and Government repression were seen as increasingly legitimating the use of force. The Manchester-based Owenite Lloyd Jones later recalled "from many conversations" with Chartists that "the physical force idea was regarded by them as something in aid of moral force - a kind of threat to be used to give effect to the arguments and remonstrances". But that also it ensured that the people would be more "fit by preparedness, and more justified by circumstances, in entering on a physical force struggle". ${ }^{14}$

Chartism in the cotton district began well along the continuum of moraland physical-force strategies. For virtually every local association and leader backed the policy of mass arming. It became the central element in the strategy of pushing open, constitutional agitation to its very limits. This arming was invariably presented as a "defensive" and "constitutional" response by an exploited people, faced with a corrupt, unrepresentative

${ }_{13}$ For recent re-assessments which recognise the dynamic interrelationship between Chartist moral- and physical-force strategies, see Epstein, The Lion of Freedom, op. cit., pp. 124-26; W. H. Maehl, Jr, "The Dynamics of Violence in Chartism: A Case Study in North-Eastern England", in: Albion, VII (1975).

14 Newcastle Weekly Chronicle, 2 August 1879. 
Government aggressively attacking popular rights. In Chartist speeches such events as the Whig prosecutions of the Swing Rioters, Irish Coercion, the Calthorpe Street Affair, the New Poor Law, the Dorchester Labourers and Glasgow Spinners prosecutions, the prosecution of the unstamped press and the proposed new police, were constantly cited as evidence supporting this view of the Government. The insistence on a defensive posture was not just an oratorical sleight-of-hand to forestall prosecutions, but fitted with deeply-held tenets of radical ideology and the radical analysis of the particular political situation in 1838-39. The defensive emphasis was further reinforced by the Tory-radical perspective of Stephens and Oastler, who led the way in advocating mass arming.

A Manchester Political Union address, and a representative of the Manchester Chartists explaining their position to the Northern Liberator, both emphasised that calls for arming were not an incitement to instant insurrection.

neither Stephens nor Oastler have ever urged us to fight. To arm they do advise us; and arm we will [. . .].

We, Sir, have taken up a purely defensive position, and shall only use arms when attacked $[\ldots] .^{\text {15 }}$

It was believed that the Government would resort to repression if the Chartists appeared to be on the point of success. Thus, the Oldham Chartists declared:

the experience of past ages tells us that an unarmed people lie at the mercy of their rulers, and that, if their murmurings have been loud or troublesome, they have been invariably silenced by the sword or the bayonet. ${ }^{16}$

Hence the Stalybridge Chartists declared that arming was

dictated by the soundest policy, and by a clear conception of what ought to be the position of a nation aspiring to be free. ${ }^{17}$

In 1839 the speeches became blunter as increasing militancy and expectancy of violence were associated with the emergence of a more exclusively working-class leadership. In Manchester, in late March, many of the middle-class leaders ceased appearing at Chartist meetings and were replaced by working men on the Political Union Council. ${ }^{18}$ One of the new militant

${ }^{15}$ Manchester and Salford Advertiser, 22 December 1838; Northern Liberator, 17 November 1838.

${ }_{16}$ Northern Star, 12 January.

${ }_{17}$ Ibid., 8 December 1838.

1817 middle-class leaders appeared at Manchester Chartist events 3 or more times between September 1838 and March 1839, but only 3 appeared so frequently from March 
leaders, the spinner William Butterworth, described this change entirely in terms of getting "working men to sit on the Council" to replace the original middle-class men. He related this to the need to turn words into actions, and bluntly declared that "the trial of moral force, it is all a farce; the thing will not be settled until physical force is brought into action." The new council were also "satisfied that petitioning would not do", and were "for ulterior measures". A new delegate, the mason Christopher Dean, was sent to the Convention, with great stress on the fact that he was a working man. ${ }^{19}$ At Bolton also, a new working-class Convention delegate, John Warden (a gardener) was chosen, as he was "from that class on whom the evils of class legislation have been made to operate most severely". ${ }^{20}$ Here also middle-class leaders dropped out of the agitation. The new delegates, Dean and Warden, were both committed to the confrontational generalstrike strategy of the National Holiday.

At Heywood extremely militant leaders began to attack the Convention for having wasted too much time and having thus allowed the Government to reinforce the troops in the North. ${ }^{21}$ Few went as far as such explicit criticism, but there was certainly widespread frustration at the apparently interminable delays in the Convention presenting the petition and initiating decisive action to obtain the Charter. This was clearly revealed at an important delegate meeting at Rochdale, attended by 32 delegates ( 28 of whom were from the cotton district). It was aimed, as Timothy Higgins, the militant Ashton secretary, said, "to push the Convention forward". ${ }^{22}$ The situation in the cotton district was extremely tense by the early summer of 1839 , not least because here physical-force Chartism had not been a matter of mere rhetoric, but also genuinely extensive arming.

\section{Arming}

The extent of arming is a difficult matter to assess, not only because of the vagaries of the evidence, but also because of the manner in which the topic touches some very sensitive political nerves. On the Left, there has sometimes been a tendency to get carried away with romantic images of armed

to July (and all 3 were former manual workers). 10 of the 17 did not appear at all after March.

19 Manchester Guardian, 8 May; Manchester and Salford Advertiser, 11 May; Northern Star, 6 April and 11 May.

20 Bolton Free Press, 20 April; Northern Star, 20 April; Robertson to Lovett, 15 April, British Museum, Additional Manuscripts 34245 A, ff. 33-34.

${ }^{21}$ Heywood Democrat, 6 June (Bury Public Library); M. Fletcher, Letters to the Inhabitants of Bury (Bury, 1852), No IX.

22 Manchester and Salford Advertiser, 29 June. 
workers tramping over moonlit moors. On the Right, there has been a marked reluctance to face the reality that arming was not entirely a figment of the imagination of half-crazed Chartist extremists and panic-stricken magistrates. Yet an assessment is required and is indeed overdue. For the extent of arming is an absolutely vital factor in determining the extent of popular commitment to physical-force strategies. The problem is best approached by discarding entirely the obviously dubious accounts speaking in vague terms about distant areas, and by leaving on one side the general and therefore necessarily vague local estimations of arming. It is more illuminating to focus instead on well-informed observers speaking of specific developments in their own localities, actual finds of arms and fully authenticated observations of drilling.

The first plausible reports of arming came towards the very end of 1838 . The factory-dominated Ashton area certainly led the way, with a memorial of local mill-owners speaking of arming by "great numbers", and the magistrates confirming it had occurred to "a considerable extent". ${ }^{23}$ Cutlasses and pikes were soon on open sale in some Stalybridge shops and in Hyde market-place. ${ }^{24}$ A representative of the Stockport Advertiser and a local magistrate procured pikes as examples. Another magistrate sent in the deposition of a man who had bought two pikes from the Ashton Chartist John Broadbent. ${ }^{25}$ On 4 May 1839 the Ashton constables arrested four men for drilling, having seen detachments of up to a hundred drilling over the past month. ${ }^{26}$ At Middleton also there were reports of arming in December 1838, shots being fired every night by February 1839 , and renewed arming and drilling in May. ${ }^{27}$ The same pattern is discernible in the Leigh area, that is of early arming and then a renewed burst in April-May. ${ }^{28}$ There was

${ }_{23}$ Higginbottom, Buckley and Lord to Russell, 12 December 1838, HO 52/37; Bentley to Russell, 17 December 1838, and Mills to Russell, 29 December 1838, HO 40/38.

24 Manchester Guardian, 16 March; Manchester Courier, 16 March; Chorlton and Hibbert to Russell, 23 April, HO 40/37.

25 Stockport Advertiser, 15 March; Brookes to Wemyss, 21 April, HO 40/43; Evans to Russell, 4 May, HO 40/37.

26 Manchester Guardian, 8 May; Manchester and Salford Advertiser, 11 May; Treasury Solicitor's Papers 11/1030/4424, B to G.

27 Stockport Advertiser, 14 December 1838; Bolton Chronicle, 15 December 1838; Manchester Guardian, 16, 20 and 23 February; Manchester Courier, 16 February, 11, 18 and 25 May; Northern Star, 30 March; Bolton Free Press, 4 May; Manchester and Salford Advertiser, 4 May. At nearby Failsworth two Chartist pikes were later preserved by the local Liberal club, see A. Marcroft, Oldham Liberal Bazaar Souvenir. Landmarks of Local Liberalism (Oldham, 1913), p. 103.

28 Smith to Russell, 6 December 1838; id. to Derby, 6 December 1838; Wilkinson to Russell, 12 December 1838; Manchester constables to Russell, 2 December 1838, HO 52/37; Manchester and Salford Advertiser, 29 December 1838; Bolton Chronicle, 29 December 1838; Egerton to Russell, 3 January, Bancks to Russell, 11 May, and Sander- 
certainly arming, gun fire at night and pike making at Heywood. ${ }^{29}$ In Rochdale arms were on sale in the market-place, and pikes were discovered on the premises of an iron foundry. ${ }^{30}$ There was also arming and drilling in some of the villages around Oldham. ${ }^{31}$ In Oldham itself some arming took place and pikes were also seen on sale. ${ }^{32}$ But in both Rochdale and Oldham the scale of arming seems to have been limited. At first Stockport was also backward, but from April, pikes were on open sale. The Mayor became convinced, with good reason, that a "very alarming quantity" of pikes and daggers were being distributed, and sent in an example of a pike bought at one of the Chartist rooms. ${ }^{33}$ In Bury the scale of arming can only definitely be said to have assumed significant proportions in the early summer. ${ }^{34}$ In Bolton pike making certainly only became widespread in July. ${ }^{35}$ Then the deputy constable actually visited two smithies given over completely to pike making. One was that of a leading Chartist, Daniel Cowle, who had three men and a boy engaged in making them..$^{36}$

The varying time-scale of arming accurately reflected the differing pattern of Chartist strength (most dramatically with Ashton leading the way, then fading, and Bolton Chartism surging strongly quite late), for the two were indissolubly linked in this area. The nature of the arming was also conditioned by the strength of the police and army presence. Arming was

son and Newton to Russell, 22 May, HO 40/37; Manchester Guardian, 13 April; Manchester and Salford Advertiser, 27 April; Bolton Free Press, 11 May. An old soldier, William Douglas, was reputed to have drilled the Chartists, J. Lunn, Leigh. The Historical Past of a Lancashire Borough (Leigh, n.d.), p. 86.

${ }^{29}$ Manchester Courier, 2 March; Bolton Free Press, 9 March; Northern Star, 18 May; Manchester Guardian, 25 May; Chadwick to Russell, 8 March, HO 40/37; Wemyss to Phillipps, 23 July and 6 August, HO 40/43.

30 Royds to Russell, 24 December 1838, HO 40/37; Manchester Guardian, 6 March and 1 May.

${ }^{31}$ For Lees see Mills to Russell, 29 December 1838; Manchester Guardian, 1 May; Manchester and Salford Advertiser, 4 May. For Hollinwood see Butterworth Diary, 24 April, Oldham Public Library; Manchester Guardian, 27 April; Hordern, Evans and Hibbert to Russell, 1 May, HO 40/37.

32 Ibid.; Mills to Russell, 17 May, HO 40/37; Ben Brierley, Home Memories and Recollections of a Life (Manchester, 1886), p. 24.

33 Stockport Advertiser, 28 March, 19 April and 17 May; Pendlebury to Russell, 29 July and 9 August, HO 40/41. For a detailed account of Stockport Chartism see C. A. N. Reid, "The Chartist Movement in Stockport" (unpublished M.A., Hull, 1974).

${ }^{34}$ Grundy to Russell, 19 July, and Walker to Russell, 25 July, HO 40/37; Wemyss to Phillipps, 29 July, 6 and 11 August, HO 40/43.

35 Darbishire to Russell, 9, 11 and 14 July, HO 40/44; Wemyss to Phillipps, 14 and 16 July, HO 40/43.

36 Lomax to Russell, 15 July, HO 40/44. When another leading Chartist, George Lloyd (a joiner), was arrested, pike staves were found in his room, see Bolton Free Press, 17 August; Winder to Russell, 17 August, $\mathrm{HO}$ 40/44. 
most open in the villages. Thus for example in Kearsley, just south of Bolton, a publican and his wife reported a group of spinners bringing pikes into their pub and saying that Kearsley was a good place to come, as there was only one constable. That same Kearsley parish constable went, somewhat bewildered, to ask the Bolton magistrates what action he should take about a travelling salesman who arrived with his pikes every pay day. ${ }^{37}$ The strength of the authorities in Manchester encouraged greater Chartist caution. But pikes were seen at some meetings and at least one mould for making pikes was found. ${ }^{38}$ Furthermore the police observed drilling, involving about a hundred men, and made several arrests in May. ${ }^{39}$

Further evidence linked key members of the local Chartist leadership with an extensive scheme to supply fire-arms into the area. Peter Murray McDouall, who had replaced Stephens as the Convention delegate from Ashton, approached a Birmingham arms dealer in May. He ordered twenty muskets, offering to pay for them immediately, and asking for them to be sent to an Ashton pub, the Bush Inn (of which an active Chartist, James Duke, was publican). McDouall said "there would be from five hundred to a thousand more wanted if those were approved of." 40 This order was refused, but subsequently a willing arms dealer was found. The story here begins with the arrest of Timothy Higgins, the Ashton Chartist secretary, and the discovery of 27 "stand of arms" (including 17 muskets) in his home. Higgins was shown to be acting as an agent for a Birmingham gunsmith, George Thompson. A letter was found, from Birmingham, addressed to the Ashton Chartist, Abel Williamson, at the Bush Inn about a shipment of 20 guns. Higgins himself seems to have received about 50 muskets, also sent to the Bush Inn. ${ }^{41}$ At Stockport the arrival of a large crate of arms at the home of the Chartist James Mitchell also alerted the Stockport police. They arrested him and seized a crate of muskets and other arms. During the night, backed by the military, they arrested seven more Chartists and found arms in the houses of six of them. Further arrests were made, and it was

37 Lomax to Russell, 25 March, HO 40/37; Manchester Guardian, 16 March.

38 Manchester and Salford Advertiser, 30 March and 17 August; Manchester Guardian, 27 July. Arming with pikes certainly took place in the adjoining village of Gorton, see John Higson, The Gorton Historical Recorder (Gorton, 1852), p. 185.

${ }^{39}$ Manchester Guardian, 4, 8 and 11 May; Treasury Solicitor's Papers 11/815/2683. The leader of the drilling was an ex-soldier.

40 Scholefield (Mayor of Birmingham) to Russell, 9 May, HO 40/50.

41 Manchester and Salford Advertiser, 6 and $20 \mathrm{July}$; Northern Star, 6 and $20 \mathrm{July}$; Manchester Guardian, 17 July; Jowett to Russell, 3 July, HO 40/37; Treasury Solicitor's Papers 11/1030/4424 A, Case against Higgins. 
revealed that a mass of documentary evidence had been discovered.$^{42}$ The Birmingham gunsmith George Thompson was again the supplier, and he was therefore arrested, in Birmingham, by the Stockport police. Further documents were found at Birmingham implicating the Ashton Chartist leadership, letters about arms from John Broadbent, a guarantee signed by James Duke and McDouall for arms to be sent to Higgins, and a separate letter from Duke ordering guns. ${ }^{43}$

The Manchester police, acting on information from Stockport, arrested John Livesey, the son-in-law of one of the key Manchester Chartist leaders, James Wheeler. In Livesey's house the police found a selection of arms, including 2 muskets and receipts for two cases of 24 guns, presumably already sold. Livesey had also become an agent for the gunsmith Thompson. Other documents were found implicating the Manchester Chartist leadership, a letter from G. H. Smith, (treasurer of the Hulme association) ordering guns, and a letter from R. J. Richardson (Manchester's first delegate to the Convention) counter-manding an earlier order for guns. ${ }^{44}$ In addition letters ordering guns from Thompson were found from John Rawson, secretary of the Bury Chartists, George Lloyd, one of the main Bolton leaders, and the key Bradford leader, Peter Bussey.$^{45}$ The network thus spread beyond Lancashire, and indeed considerable numbers of Thompson's guns had apparently also been sold in the Potteries. ${ }^{46}$

What points then can be made by way of a general assessment? Firstly, there can be no doubt about the fact that the local Chartist leadership was deeply involved in arms supplying. Secondly, the evidence suggests that arming involving at least home-made pikes and similar weapons was quite extensive, not perhaps as widespread as some Chartist boasts and alarmist reports alleged, but probably involving hundreds in each of the militant

42 Stockport Advertiser, 2 and 9 August; North Cheshire Reformer, 2 and 9 August; Manchester Guardian, 3 August; Pendlebury to Russell, 31 July, HO 40/41; Thomas to Wemyss, 31 July, HO 40/43. A large amount of evidence, including verbatim copies of letters about the supply of guns, can be found in Assizes 65/2, Public Record Office.

${ }^{43}$ Manchester and Salford Advertiser, 3 and 10 August; Manchester Guardian, 7 and 17 August. See also the later trial report in Manchester Times, 18 April 1840; Interviews with Duke and Broadbent, HƠ 20/10.

44 Manchester and Salford Advertiser, 10 August; Interview with Livesey, HO 20/10; Manchester Guardian, 10 and 17 August; Potter to Russell, 9 August, HO 40/43. See Assizes 65/2 for a copy of Richardson's letter asking for his money to be refunded.

${ }^{45}$ Manchester Guardian, 17 August; the report of Lloyd's trial in Manchester Chronicle and Salford Standard, 11 April 1840; for further evidence about Rawson selling guns, see Wemyss to Phillipps, 6 August.

${ }^{46}$ Th. Dunning, "The Reminiscences of Thomas Dunning (1813-1894) and the Nantwich Shoemakers' Case of 1834", in: Transactions of the Lancashire and Cheshire Antiquarian Society, 1947, p. 114. 
localities. ${ }^{47}$ Thirdly, although obviously the extent of arming cannot be determined exactly, there is firm evidence that a strong demand for arms existed. Private letters, actually ordering guns, clearly demonstrated that. John Livesey's order to Thompson included these remarks:

Please to send as quick as you possibly can. My place is established, and they haunt me by dozens, and I have nothing to sell, I sold the last on Sunday.

G. H. Smith's letter said he could sell hundreds if they could be supplied, and George Lloyd's letter said "he could in a few hours sell hundreds of them if he had them." ${ }^{48}$

Overall, this evidence suggests a pattern of initial arming in NovemberDecember 1838 , with a renewed burst of arming around May 1839, and then again in July. This fits well with more general assessments. ${ }^{49}$ This firm evidence of Chartist arming also makes the more impressionistic verdicts that very large-scale arming and drilling had occurred appear far more plausible. ${ }^{50}$ It was not a figment of the imagination of a few panic-stricken magistrates. But finally, apart from the odd reference to the involvement of old soldiers and the discovery of several copies of Colonel Macerone's wellknown book on street fighting, there is little or no evidence to suggest much military expertise in the Chartist ranks. Benjamin Brierley, who remembered having "to turn my father's grindstone whilst rebelliously-disposed amateur soldiers ground their pikes", was perhaps justified in his sarcasm.

The Queen was to be dethroned and the president of a Republic would take her place. This would be a very easy task. Ten thousand trained pike-men

47 In a secret session at the Convention, McDouall, one of the most vociferous in claiming in public that working-class arming was well advanced, "admitted that if he named 400 armed men for his neighbourhood he would probably overstate the number." Robert Lowery, Radical and Chartist, ed. by B. Harrison and P. Hollis (London, 1979), p. 143.

48 Manchester Guardian, 14 August; Manchester Chronicle and Salford Standard, 11 April 1840; Foster to Phillipps, 10 August, HO 40/43. Thompson was not a Chartist, but was simply seeking a profitable trade, see the interview with Thompson, HO 20/10.

${ }^{49}$ See, e.g., the comments that Lancashire reports show "an increased disposition to arm", Russell to Foster, 2 May, HO 41/13; and, in July, the belief of the Manchester-area military commander, Colonel Wemyss, that three hundred "stand of arms" had reached Stockport in one week, and the Northern-area commander, General Napier, that "pikemaking is redoubled". W. Napier, The Life and Opinions of General Sir Charles James Napier (London, 1857), II, pp. 52, 54, 56.

so See, e.g., the references to "very large quantities of pikes and fire-arms", and "the drilling and exercising of large bodies of men", Manchester Guardian, 4 May (leader); and to "thousands" being "armed and ready for mischief", Mott (Assistant Poor Law Commissioner) to Lefevre, 22 March, Ministry of Health Papers 12/5593, Public Record Office. Mott's view was specifically endorsed by the very experienced Manchester-based magistrate J. F. Foster, see Foster to Russell, 11 April, HO 52/40. 
would sweep England through; and Hollinwood could furnish a contingent of at least a thousand. ${ }^{51}$

Yet, irrespective of such naïveté, the fact remained that substantial quantities of arms were in working-class hands. There was also a crisis atmosphere, in which there was intense and widespread disaffection with the Government, and in which extravagant hopes and expectations had been aroused. However, the nature and limitations of radical tactics and the calculated restraint of the authorities helped to ensure that the amount of actual physical violence in the cotton district in 1839 remained limited.

\section{Radical tactics and the State}

During the entire period from 1815 to 1848 the central radical tactic consisted of applying pressure by means of a constitutional campaign, utilising mass-platform agitation and mass petitioning..$^{52}$ It had important strengths. It provided an apparently legal method of mobilising popular support, creating an atmosphere of excitement, inculcating a spirit of mass defiance, publicising radical arguments and pressurising the Government. This approach appeared to offer the best prospects for engineering a decisive confrontation between a mobilised, united people and an unrepresentative Government. According to the radical analysis it was likely to result in the Government resorting to acts of repression, which would irretrievably alienate public opinion and stimulate a defensive explosion of protest, which would overwhelm the forces of reaction. Alternatively it was believed that if the Government did not act, it would be faced with the inexorable progress of the mass-platform agitation to the overwhelming display of numbers, against which there would be no answer or defence. The Chartist campaign of 1838-39 represented the high point of this constitutional strategy. One single national petition was linked with one unified campaign. The rhetoric was probably the most daring and expectations were raised to the highest pitch. The 1839 Convention came closer to the idea of an anti-Parliament than any other..$^{53}$ The campaign was able to draw upon the experience of 1819 , but also gained added inspiration and plausibility from the apparent success of the mass agitations for Catholic

51 Brierley, Home Memories, op. cit., p. 24.

${ }^{52}$ For a penetrating analysis see Belchem, "Henry Hunt", loc. cit.; id., "Republicanism, Popular Constitutionalism and the Radical Platform in Early Nineteenth-Century England", in Social History, VI (1981); id., "1848: Feargus O'Connor and the Collapse of the Mass Platform", in: The Chartist Experience.

${ }_{53}$ Epstein, The Lion of Freedom, ch. 4; Parssinen, "Association, Convention and AntiParliament", loc. cit., pp. 521-30; H. Jephson, The Platform. Its Rise and Progress (London, 1892), II, ch. 17. 
Emancipation and the Reform Bill. The constitutional strategy was consciously pushed to its limits in 1839 . Lancashire, from the first huge Kersal Moor meeting to the attempted general strike strategy of the National Holiday, largely spearheaded this process.

Yet the whole constitutional strategy had fatal flaws. The violent rhetoric tended to scare off moderates and potential middle-class allies, thus postponing endlessly the point at which a united people would face the numerically few, who, it was believed, had a genuine interest in preserving the existing system of government. On the other hand, militants became disillusioned when no decisive action appeared to follow all the threats. Furthermore, in adopting a firmly defensive posture with regard to physical action, the initiative was handed over to the Government. So long as the authorities did not act in a quite outrageously provocative manner, there would be no universally agreed point at which resistance was deemed to be justified.

Both the Chartist and military leadership believed the most likely catalyst for widespread violence was a Peterloo-style incident. As Stockport's James Mitchell put it, "let the people be Peterloo'd and the whole country will be Moscow'd"'. ${ }^{44}$ But the Chartist leadership's concern to prevent "premature", that is piecemeal, localised "outbreaks", the lack of any major strikes in the area, and the careful restraint of the military command removed the most likely causes of an unpremeditated clash between soldiers and workers. ${ }^{55}$ Indeed the authorities carefully avoided needlessly provocative action. For example, they did not proceed with prosecution cases against the Northern Star, the anti-Poor-Law speakers, and the meetings to elect Convention delegates. They also delayed the introduction of the New Poor Law into Manchester. ${ }^{56}$ Arguably the more relaxed attitude towards the problems of public order, which differentiated the Whigs from the Conservatives, ${ }^{57}$ was more appropriate to the situation of 1838-39. For Government caution resulted in local middle-class reformers having time to be more scared and repelled by Chartist violence than Government repression. The abdication of local middle-class responsibility for public order, which had allowed the 1831 Bristol riots to assume such

${ }^{54}$ Stockport Advertiser, 19 July.

55 Epstein, The Lion of Freedom, pp. 122, 154-55, 163; R. A. Sykes, "Early Chartism and Trade Unionism in South-East Lancashire", in: The Chartist Experience, pp. 16668.

56 Cases No 12, 21 and 44, HO 48/32; Cases No 2-4 and 7, HO 48/33; Fox Maule to Foster, 6 February, Ministry of Health Papers 12/6039; Manchester Churchwardens to Russell, 14 February, HO 44/33.

${ }^{57}$ F. C. Mather, Public Order in the Age of the Chartists (Manchester, 1959). 
major proportions, did not occur. ${ }^{58}$ More vigorous action to arrest Chartist leaders was only forcibly urged on local magistrates in the spring of 1839 , after major troop reinforcements had been moved into the manufacturing districts. ${ }^{59}$ Throughout this time the genuinely compassionate commander of the Northern district, Major General Napier, and the Lancashire commander, Colonel Wemyss, took great care to avoid any unnecessary provocation or accidental collision with the Chartists. There was a real danger.

The Chartists are numerous, and should one detachment be destroyed the soldiers would lose confidence; they would be shaken while the rebels would be exalted beyond measure. ${ }^{60}$

But no such clash materialised, and it was against the background of the debilitating effect on confidence, brought by the increasing strength of the authorities and increasing number of arrests, that the Chartists had to move towards taking positive action.

Positive action meant the ulterior measures set out in the manifesto issued by the Convention in May 1839 . They comprised plans to withdraw all money from the banks, to convert all paper money into gold, to prepare for a Sacred Month, a month's general strike (which was paired with a call for people simultaneously to abstain from intoxicating drink), to arm themselves, to elect Chartist candidates by a show of hands at subsequent elections, to "deal exclusively" with Chartists, and to pledge to contend only for the Charter and obey the Convention. These proposals have largely escaped analysis by historians. ${ }^{61}$ This is a strange phenomenon, for in the cold light of day and from a twentieth-century perspective, they appear to be an odd collection of tactics for a confrontationalist workingclass movement seeking a revolutionary change in the political system, to be so unanimously agreed upon. Some of the proposals were obviously open-ended, long-term strategies, as in the case of the election plan, or decidedly incongruous in the violent atmosphere of 1839 , as in the call for abstention from exciseable drink. There is an authentic ring to the memories of Adam Rushton of when, as an enthusiastic Chartist, he attended Chartist meetings in Macclesfield. He remembered meetings about ab-

${ }^{58}$ S. Thomas, The Bristol Riots (Bristol, 1974), pp. 9-10.

59 Russell to Foster, 2 May; id. to the Lord Lieutenants of all counties, 4 May, HO 41/13; F. C. Mather, "The Government and the Chartists", in: Chartist Studies, op. cit., pp. 378-81.

${ }^{60}$ Napier, General Sir Charles James Napier, op. cit., II, p. 59.

${ }^{61}$ Epstein, The Lion of Freedom, pp. 157-58, correctly comments that they were a "familiar catalogue of ultra-radical tactics". William Lovett, who said he wrote the actual address, records that there were only trifling objections, and virtually unanimous endorsement from Convention delegates, The Life and Struggles of William Lovett, 2nd ed. (London, 1967), pp. 171-77. 
staining from alcohol as being a total farce, with men attending with beer on their breath. He also commented:

The discussion as to the run on the savings banks was quite ludicrous. No one would own to having any deposits. I had a small amnunt in the bank, but said nothing about it. ${ }^{62}$

The Manchester Owenite Lloyd Jones later stressed the impracticability of all the measures, but especially and surely justifiably the proposals to run the banks, which were addressed to a working-class audience in "a season of bad trade and when money had hardly any existence amongst them". ${ }^{63}$

A common feature of the ulterior measures was that they depended on an overwhelming display of popular support, a contest of 99 to $1 .{ }^{64}$ Chartist tactics in 1839 remained imprisoned within a framework imposed by the radical heritage, and were only very partially adapted to fit the actual pattern of Chartist support, in other words to suit an urban working class, which was very unevenly distributed across the country. Recently some very important work by Gareth Stedman Jones has stressed the importance of examining the language and ideology of early-nineteenth-century radicalism more seriously. He has stressed the need to impose a more "political" interpretation of Chartism over the previously dominant "social" explanation, which has for so long hindered our understanding of Chartist ideology. ${ }^{65}$

In fact Chartism was deeply rooted in a radical political tradition, which still bore the heavy imprint of its eighteenth-century origins. Two key tenets, which continued to be very influential throughout the first half of the nineteenth century, need to be emphasised. Firstly, the central image remained one of an excluded "people", denied access to political power, and exploited by a parasitic ruling class. In this image, the number whose "real" permanent interest lay in maintaining the status quo was believed to be very small indeed. Secondly, there was a continued emphasis that

${ }^{62}$ A. Rushton, My Life as Farmer's Boy, Factory Lad, Teacher and Preacher (Manchester, 1909), p. 66.

${ }^{63}$ Newcastle Weekly Chronicle, 6 September 1879 . For one quite rare critical comment by a Chartist in 1839, dismissing all but the strike plan as "Whig" measures, see Heywood Democrat, 6 June.

${ }^{64}$ Such assumptions about the balance of forces in any final confrontation were deeply ingrained into radical ideology, see Prothero, "William Benbow", loc. cit., passim, but esp. pp. $145,165-66$.

${ }_{65}$ Stedman Jones, "The Language of Chartism", loc. cit., passim, but esp. pp. 3-12. By social interpretation Stedman Jones means the approaches so heavily conditioned by the assumption that Chartism was essentially a social phenomenon produced by, in varying degrees, the Industrial Revolution, poverty and class-consciousness that they have consequently neglected the specific political and ideological form and content of the movement. 
political, not economic, power lay at the root of exploitation. To the radicals economic inequality derived from political inequality rather than the other way around. The social interpretation has long obscured this vitally important aspect of radical ideology, and thus for long obscured the reasons why Chartists so persistently sought political solutions for what historians have seen as their social and economic problems. The Reform Act of 1832 came to have pivotal importance in the Chartist analysis, as the point at which the middle class betrayed the working class. The excluded "people" now more or less conformed to the manual working class. Yet the crime of the middle class remained in the last resort one of political betrayal. Whilst the radicals were quite prepared to treat the large millowners as inveterate enemies, they certainly were not prepared to view the middle class as a whole as necessarily opposed to the interests of the working class on a permanent basis. Hence the issue about constructing an alliance with sections of the middle class remained a recurrent theme throughout the Chartist period. ${ }^{66}$ The 1839 manifesto of the Convention was quite in line with other Chartist declarations when it declared that "our political burdens and social grievances are the result of exclusive law making", and hoped that selfish middle-class pride would be overcome and "common interests" would unite them with the Chartists. ${ }^{67}$

The experience of middle-class opposition hardening during the course of 1838-39 revealed a gap between radical ideology and social reality. In addition the discovery, when the Convention met and the National Petition was put together, that vast areas of agricultural Britain had played virtually no part in the agitation revealed a further gap. The Convention spent much time trying to "agitate" very unlikely agricultural areas. For delegates like Newcastle's Robert Lowery, who had believed the entire country was "up to the mark", it was a shock to discover the political ignorance and indifference in South-West England. ${ }^{68}$ For Chartists to admit the reality of the uneven nature of their popular support, and the strength of the forces opposing them, meant undermining the moral strength they derived from claiming the overwhelming majority of the population had an interest in supporting them, that it really was 99 to 1 . Such an admission of weakness elsewhere also risked destroying the credibility of the movement in its areas of strength, given the prior emphasis on the ideological and tactical necessity of mobilising the entire "people". Yet the Chartist failure to face this social reality led to growing tactical confusion, and ultimately to their

${ }^{66}$ For further discussion of such issues, see Sykes, "Popular Politics and Trade Unionism", op. cit., esp. chs 7, 10 and 14.

67 The Life and Struggles of William Lovett, op. cit., pp. 173, 175.

68 Robert Lowery, op. cit., pp. 127, 128-30, 142. 
very real strength in the industrial areas being dissipated in the summer of 1839.

Finally, the experience of the first Chartist campaign called into question the radical analysis of the State, which was still heavily conditioned by memories of the Pittite and post-war repression. It was not only the 1840 commutation of the death sentence on Frost, Williams and Jones for their part in the Monmouth rising which raised doubts about the Chartist image of the State as being likely to be crudely repressive when challenged. ${ }^{69}$ Indeed that was only the culmination of a process in which the competence and flexibility of the authorities and their confidence about retaining middle-class support increasingly confounded Chartist expectations in 1838-40. This was especially serious as so much of radical tactical thinking, permeated by a defensive mentality, depended upon the State precipitating confrontation in a crude, clear-cut, predictable fashion. The introduction of the London police into Birmingham, and the subsequent riots in July 1839, provided the nearest thing to a Peterloo-style incident. It was portrayed as such by the Chartists, and certainly powerfully contributed towards creating a more threatening atmosphere..$^{70}$ But the Birmingham events were not so unambiguous or momentous as to be the signal for spontaneous insurrection, and indeed it remained unclear as to what event possibly could be so clear cut and obvious. ${ }^{71}$ Hence the Chartists were forced to move towards positive action amidst growing tactical confusion and uncertainty.

\section{The National Holiday and the climax of Chartism in 1839, 1}

The only really plausible option amongst the Convention's ulterior measures was the general strike, the Sacred Month or, as it was usually called in Lancashire, the National Holiday. It was certainly the only strategy upon which serious hopes were placed in the cotton district, and indeed other militant localities..$^{72}$ There were differing conceptions of what was entailed in this familiar radical strategy. But undoubtedly predominant in Lancashire was the formula, proposed by William Benbow in his famous 1832 pamphlet, for a month-long general strike. It was intended to be an initially peaceful act, designed to precipitate a decisive confrontation be-

69 The significance of this event has been stressed by Dorothy Thompson, see "Chartism as a Historical Subject", in: Bulletin of the Society for the Study of Labour History, No 20 (1970), p. 12; id., The Early Chartists (London, 1971), p. 27.

70 Epstein, The Lion of Freedom, pp. 170-71.

${ }^{71}$ Of course not even Peterloo had unified radicals on a course of spontaneous resistance, see Belchem, "Henry Hunt", pp. 760-61; id. "Republicanism, Popular Constitutionalism and the Radical Platform", loc. cit., pp. 14-17.

$n$ Robert Lowery, p. 135. 
tween the people and their rulers. ${ }^{73}$ Local Chartist leaders could be extremely blunt about this. Thus, amongst the Bolton Chartists, John Warden favoured it precisely because it was "tantamount to a national insurrection", and John Gillespie, another advocate of the strategy, commented that "Dr. Taylor said a sacred month meant a physical revolution, and he always understood the same." 74 In the atmosphere of 1839 in Lancashire it could hardly be seen as anything else. Yet, despite the very militant and indeed often class-conscious tone of local discussions of the strike, the process of implementation continued to be seen in very traditional radical terms. It was, for instance, not seen as a syndicalist scheme involving a major role for the trade unions. It was viewed as a demonstration by the "people" against the Government, a demonstration which should involve an overwhelming majority of the population. Hence there was enormous concern with making sure it was a truly national strike and, consequently, a reliance upon the national leadership taking the initiative.

In the Convention attention inevitably focused upon the National Holiday by the early summer of 1839 . In the extended discussions Dean for Manchester, Warden for Bolton, Fletcher for Bury and McDouall for Ashton all spoke in favour of the plan; Deegan for Hyde was rather ambiguous, and Taylor for Rochdale and Mills for Oldham clearly sceptical. On $16 \mathrm{July}$, in the absence of many delegates, a resolution was passed, calling for the Sacred Month to begin on 12 August. ${ }^{75}$ But in complex discussions commencing on 22 July O'Connor and O'Brien, the two most prestigious national leaders (who had both been absent when that vote had been taken), began to orchestrate a retreat from the decision. Inevitably this began to undermine confidence in the National Holiday strategy. Then on 3 August, the Northern Star, the crucial organ of Chartist communication, which was at its all-time peak in terms of circulation and influence, carried a vitally important leader and letter from O'Connor arguing against a month's strike, and in favour of a three-day holiday on 12 August. This proposal was officially endorsed by the council of the Convention on 6

73 See Prothero, "William Benbow", passim, for the best discussion. In 1839 Benbow was himself active in the Manchester area. He lectured specifically on the Holiday scheme at Middleton and Bolton, see Manchester Guardian, 16 February; Bolton Free Press, 29 June. Copies of his pamphlet were found in the possession of several arrested Chartists, see Assizes 65/2.

74 Northern Star, 6 July; Bolton Free Press, 13 July. Cf. Lowery's similar comments, Robert Lowery, p. 142.

${ }^{75}$ Northern Star, 6, 13, 20 and 27 July. By far the best discussion of the Convention's deliberations is in Epstein, The Lion of Freedom, pp. 171-81. 
August. This climbdown was then publicised in the Star of 10 August, on the very eve of the proposed strike. ${ }^{76}$

From a national standpoint the Convention's decision was understandable. Out of twenty letters reaching it on the strike, sixteen were hostile, ${ }^{77}$ and there was much truth in O'Connor's arguments that many areas would not strike. But in South Lancashire it was a bitter, disorientating blow. John Deegan sent in the resolution of three thousand Hyde Chartists that

our delegate John Deegan, be instructed to recall his vote in the Convention (for the present) for the fixing of a day to commence the sacred month. For although we in Hyde are fully prepared yet we believe the whole country is not and in consequence we had better put off the day than have a failure.

Deegan added his own comments, in a private letter be it remembered, not a piece of bravado at a public meeting.

The resolution was agreed to very reluctantly for in Hyde they want to begin. I know not whether the people can be prevailed upon to remain quiet much longer. They are exceedingly indignant at the numerous arrests that are taking place in this neighbourhood. ${ }^{78}$

For the first time there is evidence of serious criticism of O'Connor. In Bolton Warden and Lloyd bitterly denounced his actions over the National Holiday. ${ }^{79}$ James Taylor reported the adverse reaction in Rochdale and Middleton.

The Convention is suffering in character with the people through it. And Mr. O'Connor is getting a good share of the blame which is thrown upon the Convention in this matter for his leading article in the Star of last Saturday on this subject. I am told that in two or three districts it was suggested to have the Star burned.

The truth is the people from what I learn scarcely know what to do nor whom to confide in. Wishing the Convention well out of the perplexing affair. ${ }^{80}$

The confusion was understandable. A month's strike could only be seen as a means of precipitating a final decisive confrontation, the ultimate climax of an open, constitutional campaign, but a three-day strike lacked any obvious purpose. The national leadership's climbdown had been at the last

${ }^{76}$ Northern Star, 3 and 10 August. For the Star's circulation, see Epstein, The Lion of Freedom, p. 68.

$" \mathrm{~K}$. Judge, "Early Chartist Organization and the Convention of 1839", in: International Review of Social History, XX (1975), p. 393.

${ }^{78}$ Deegan to Fletcher, 6 August, British Museum, Add. Mss 34245 B, f. 110.

${ }^{79}$ Bolton Free Press, 10 August; Bolton Chronicle, 10 August.

${ }^{80}$ Taylor to Smart, 8 August, British Museum, Add. Mss 34245 B, f. 123; and see the similar comments from another militant centre, Bradford, Bussey to Smart, 6 August, ibid. 
possible moment, and the adjournment of the Convention until September left a policy and leadership vacuum. ${ }^{81}$

In the cotton district, as in other militant areas, there was a desperate need for positive action to preserve the movement's momentum and credibility. Yet the Chartists were caught in a vice between the debilitating effects on Chartist confidence of the Convention's vacillations and much more vigorous action by the authorities. In Stockport, on the night of 30 July, Mitchell and seven other leaders were arrested. As a result the network of arms supplying was smashed and further arrests followed. In Stockport itself large crowds had assembled the day after the arrests. But, after the Riot Act was read, they were successfully dispersed with only a few skirmishes involving stone throwing. ${ }^{82}$ Chartism in Stockport was suddenly left disorientated and confused. In Manchester, on 3 August, a large meeting unanimously called for a strike on 12 August. But between 1 a.m. and 3 a.m. that very night five of the main Chartist leaders were arrested ${ }^{83}$ The arrest of another leader, Samuel Scott, in the daylight on 4 August demonstrated the real dangers of spontaneous violence. A crowd of a thousand quickly assembled and stoned the police, who were forced to shelter in Chorlton Town Hall. Yet at precisely the moment the abdication of national leadership placed firm local leadership at such a premium, the local leaders were being removed. In the week before the National Holiday (when it was reduced to a three day strike) all meetings in Manchester were banned. ${ }^{84}$

In such circumstances, with no element of surprise and with all the available police, magistrates and soldiers ready and waiting at dawn, taking to the streets of Manchester on Monday 12 August was a project for diehard enthusiasts only. ${ }^{85}$ Nevertheless three separate Chartist crowds assembled

81 The attendance of Chartist crowds at Church services in many areas in late July and August was, perhaps, more of a symptom of this tactical confusion (as opposed to the climax of a theme of Chartist concern with religion) than is allowed in E. Yeo, "Christianity in Chartist Struggle 1838-1842", in: Past \& Present, No 91 (1981).

82 Pendlebury to Russell, 31 July; Thomas to Wemyss, 31 July; Stockport Advertiser, 2 and 9 August; North Cheshire Reformer, 2 and 9 August; Manchester Guardian, 3 August.

83 Manchester Guardian, 3 and 7 August; Manchester and Salford Advertiser, 10 August; Potter to Russell, 7 and 9 August, HO 40/43.

${ }^{84}$ Manchester Guardian, 10 August; Manchester and Salford Advertiser, 10 August; Wemyss to Phillipps, 6 August; Potter to Russell, 7 August.

${ }_{85}$ The following account is based on Manchester Guardian, 14 and 17 August; Manchester and Salford Advertiser, 17 August; Manchester Times, 17 August; Manchester Courier, 17 August; Manchester Chronicle and Salford Standard, 17 August; Wemyss to Phillipps, 12 August; Potter to Russell, 12, 13 and 15 August; Maude to Russell, 13 August, HO 40/43. 
and turned out several large factories, before being driven off by the police and soldiers. Tuesday was much quieter, with only two of the larger mills being closed, and on Wednesday Manchester returned to normal. There had been considerable violence, with stone-throwing crowds of perhaps two thousand at their height, and many arrests. After the Newport rising the Guardian remarked that it had been only the lack of leadership which had allowed them to escape "insurrection in this neighbourhood" on 12 August. At the time it had correctly said that, if a strike had been enforced in Manchester, "a flame would have been lighted which would not only have swept over the whole southern part of the county", but also spread to much of the manufacturing districts. ${ }^{86}$ In the 1842 Plug Strike success at Manchester was the decisive development leading to the strike spreading elsewhere. In 1839 failure at Manchester equally decisively weakened the whole strike throughout the region. Certainly in Manchester the apparent lack of consultation with the local trade unions had not helped the chances of mounting a successful strike. There does seem to have been greater involvement with the unions in Bolton and Bury, where there was greater success. ${ }^{87}$ But probably more important was the relative weakness of the military and police forces outside Manchester. This factor, the strength of the forces at the disposal of the authorities, combined with the extent to which Chartist momentum had been maintained and the local leadership preserved intact, explains a great deal about the relative success and failure of the National Holiday in the local towns.

\section{The National Holiday and the climax of Chartism in 1839, 2}

Chartism in Bolton had started slowly, but was surging strongly by the early summer of 1839. The membership of the Working Men's Association trebled, and no local leaders had been arrested. ${ }^{88}$ It was indeed only at the very last moment, after a barrage of letters from the Home Office, that the local authorities began to take positive action, banning public meetings, swearing in special constables and trying to stop the pike making. ${ }^{89}$ The initial crowds which assembled on Monday 12 August were no larger than in Manchester, but they met with no resistance and by noon most of the

${ }^{86}$ Manchester Guardian, 14 August and 13 November (both leaders).

8 Sykes, "Early Chartism and Trade Unionism", loc. cit., pp. 162-64.

${ }^{88}$ Bolton Free Press, 29 June and 13 July; Northern Star, 20 July.

89 Phillipps to Darbishire, 17 and 30 July, 5 and 8 August, HO 41/44; Darbishire to Russell, 29 July, 4 and 11 August; Winder to Russell, 4 August, HO 40/44; Bolton Chronicle, 10 August; Bolton Free Press, 10 August. 
mills had stopped..$^{90}$ The Chartists held meetings, each larger than the preceeding one, in the early morning, mid morning and late afternoon. By this time the strike was general. Yet serious violence only erupted after the two key leaders, John Warden and George Lloyd, were arrested the next day, Tuesday. The essentially defensive mentality which permeated Chartist attitudes towards the use of force was revealed again, but so also was the manner in which violence could quickly escalate. A crowd stoned the police and soldiers, as the two prisoners were hurriedly dispatched for safe keeping in Manchester. The Riot Act was read. Tension mounted as some mills, attempting to re-start, had their windows smashed. A party of about sixty special constables attempted to make an arrest, were attacked by an ever growing crowd and forced to retreat into Little Bolton Town Hall. By the time the military arrived, the special constables had been forced to retreat upstairs and the ground floor had been totally wrecked. The soldiers had to fire into the crowd, wounding one man, before the crowd dispersed. Wednesday was quiet, although the strike continued, and on Thursday work resumed as normal. Twenty-four rioters were later convicted at the assizes (eight were acquitted) and some others were dealt with at the local magistrates' courts.

In neighbouring Bury the situation had been inflamed by serious riots against the introduction of a detachment of the London police in June. Exactly as in the Llanidloes riots in May, and indeed the Birmingham riots in July, it was the introduction of an alien police force which provoked actual violence. ${ }^{91}$ It was again largely defensive, but certainly deeply political and discriminating violence..$^{92}$ In Bury the atmosphere was embittered, but the local Chartist leadership and organisation was left intact and the movement gained momentum. At Bury also a strike began on 12 August and, although there was virtually no violence and few arrests, the strike remained solid for the three days. ${ }^{93}$ At nearby Heywood and Middleton

90 This account is based on Bolton Chronicle, 17 August; Bolton Free Press, 17 August; Manchester Courier, 17 August; Manchester and Salford Advertiser, 17 August; Manchester Guardian, 14 and 17 August; Darbishire to Russell, 12-16 and 18 August; Winder to Russell, 14, 16 and 17 August; Wemyss to Phillipps, 14 and 15 August, HO 40/44; Napier to Phillipps, 17 August, HO 40/53.

${ }^{91}$ Grundy to Russell, 5 June, HO 40/37; Manchester Guardian, 5 and 8 June. For Llanidloes see Thompson, The Early Chartists, op. cit., pp. 17, 222-25.

92 The police were seen as being intended "to spy upon" the people and possibly "a foul conspiracy" to introduce the New Poor Law. Manchester and Salford Advertiser, 15 June; Northern Star, 15 June.

${ }_{93}$ Manchester Guardian, 14 and 17 August; Manchester and Salford Advertiser, 17 August; Bolton Free Press, 17 August; Walker and Grundy to Russell, 12 August, Walker and Hargreaves to Russell, 13 August, and Walker to Russell, 14 August, HO 40/37; Wemyss to Phillipps, 16 August, HO 40/43. 
wholly successful general strikes also followed deliberate decisions by the local leadership. They were logical developments of local Chartist strength and militancy in localities, lacking an effective military or police presence. ${ }^{94}$ Further west, in the Leigh area, the Chartists were also strong and the authorities weak. On 12 and 13 August very large crowds toured the various villages, Leigh, Hindley, Atherton, Chowbent and others, stopping all work. ${ }^{95}$ On Wednesday a Chartist crowd came to Leigh to rescue two men arrested by the special constables. But they succeeded in driving back the Chartists in a very substantial conflict. Troops and police seized many pikes and made dozens of arrests ( 80 to 90 were sent to the assizes and over 40 later imprisoned).

Across most of the North and West of the district a strike was enforced, but in the East and South it was a different story. In Rochdale Chartism had never shown particular strength, the local leadership decided against striking and no strike of any significance took place. ${ }^{96}$ At Oldham also a relatively moderate leadership decided against striking and all remained quiet, a course of events which fits very badly with John Foster's picture of an exceptionally class-conscious Oldham radical movement, guided by a "revolutionary vanguard". ${ }^{97}$ The Ashton area had of course been very strong and militant, but its leadership was very badly divided by the summer of 1839. In June a major quarrel between Stephens and his replacement at the Convention, McDouall, caused a "complete disorganisation" and a decline in Chartist strength. ${ }^{98}$ McDouall still favoured a strike, but Stephens campaigned against it. ${ }^{99} \mathrm{Co}$-ordinated action was impossible. In Ashton itself some workmen did strike and there were meetings on 12 and

24 Manchester Guardian, 7, 10, 14 and 17 August; Manchester and Salford Advertiser, 10 and 17 August; Chadwick and Ashworth to Wemyss, 13 August; Wemyss to Phillipps, 14 August, HO 40/44.

${ }^{95}$ See the long report of the strike, Smith to Russell, 5 September; also Chisenholme to Russell, 13 August; Earl of Balcarres to Phillipps, 13 August, HO 40/37; Wemyss to Phillipps, 15 August; Manchester Guardian, 17 August.

96 Manchester Guardian, 14 and 17 August; Manchester and Salford Advertiser, 10 and 17 August; Wemyss to Phillipps, 14 August, HO 40/43. O'Connor had also spoken in Rochdale against a month's strike, see Northern Star, 13 July.

"7 Manchester Guardian, 14 August; Manchester and Salford Advertiser, 17 August; Northern Star, 17 August; J. Foster, Class Struggle and the Industrial Revolution (London, 1974). For further criticism of Foster on this and other points see R.A. Sykes, "Some Aspects of Working-Class Consciousness in Oldham, 1830-1842", in: Historical Journal, XXIII (1980).

98 Manchester Guardian, 29 June; Wemyss to Phillipps, 2 July, HO 40/43.

99 Interview with Stephens, HO 20/10; Stephens' Monthly Magazine, January 1840, p. 16; Stockport Advertiser, 2 August; Northern Star, 10 and 17 August. 
13 August, but there was no general strike. ${ }^{100}$ In Stalybridge the local leadership secured agreement against striking, but on the other hand the streets of Hyde were filled with Chartist crowds on 12 August. Stockport, with its main Chartist leaders on trial at the Assizes that very week, remained quiet. ${ }^{101}$ Generally it is clear the main focus of Chartist activity had moved from the Southern and Eastern edges of the region, the areas of earliest Chartist strength, to the North and West, where Chartist momentum had been best maintained. ${ }^{102}$

The National Holiday in South Lancashire was an event of major importance in the first Chartist campaign. In 1840 there were more Chartists in jails in Lancashire for offences committed during just those three days than there were jailed Chartists for all offences throughout 1839 in any other county. ${ }^{103}$ In South Lancashire it was a watershed, after which the movement instantly lost all momentum. Immediately afterwards all the Manchester papers were in very rare agreement in reporting a dramatic decline in Chartist strength. ${ }^{104}$ The Mayor of Manchester correctly identified the two crucial factors.

The arrests of the various Chartist leaders and the failure of the holiday appears to have caused a complete cessation of the Chartist agitation. ${ }^{105}$

When Chartism began to revive again in later 1840, and regular South Lancashire delegate meetings were being held, delegates from Middleton and Stalybridge both dated their decline precisely from 12 August 1839. The Rochdale delegate commented that they "had nearly gone to the wall since the 12th August". ${ }^{106}$ The National Holiday had destroyed so many of the myths which had sustained physical-force Chartism. It was seen that the troops would act against the Chartists, and fire on them, and that

100 Manchester and Salford Advertiser, 17 August; Manchester Guardian, 17 August; Manchester Chronicle and Salford Standard, 17 August.

101 North Cheshire Reformer, 16 August; Stockport Advertiser, 16 August.

102 The relative success of the strikes was not determined by minor changes in the state of trade, as is implied in D. Read, "Chartism in Manchester", in: Chartist Studies, p. 48. ${ }_{103}$ For comparative figures of prisoners see the list in Parliamentary Papers, 1840, XXXVIII, pp. 691-750. For a detailed analysis of the imprisoned Chartists, see $\mathrm{Ch}$. Godfrey, "The Chartist Prisoners, 1839-41", in: International Review of Social History, XXIV (1979). The strikes are dismissed in a single sentence as "pathetic failures" in J.T. Ward, Chartism (London, 1973), p. 132. The Northern Star carried very little news about the Lancashire strikes, which is probably the main reason why historians have missed their importance.

${ }^{104}$ Manchester Guardian, Manchester Courier, Manchester Chronicle and Salford Standard, Manchester Times, and Manchester and Salford Advertiser, all 24 August.

${ }_{105}$ Potter to Russell, 20 August, HO 40/43.

106 Northern Star, 17 October and 5 December 1840. 
disciplined troops and often even police were more than a match for unorganised crowds. Furthermore the national-leadership vacillations beforehand, and the very patchy national response to the National Holiday, clearly exposed Chartist weakness in so many areas of the country. Chartist confidence and belief in the possibilities of success suddenly collapsed. South Lancashire, only seriously rivalled by industrial Yorkshire as the powerhouse of early Chartism, was a spent force by the week after the National Holiday. The national Chartist movement was consequently fatally weakened.

In the rest of the country the National Holiday often passed fairly quietly. This was true even in handloom-weaving North Lancashire, further west at Wigan and, less surprisingly, on Merseyside, never a Chartist stronghold. ${ }^{107}$ However, there were substantial strikes and serious disturbances in and around Nottingham and Mansfield, as well as in Macclesfield. ${ }^{108}$ There were also significant strikes in the far North-East, in numerous Tyneside villages, and in the far North-West, in Carlisle as well as in nearby Wigton, Dalston and Cockermouth. ${ }^{109}$ On the other hand, although there were meetings and disturbances in some towns, Yorkshire remained much quieter than Lancashire. ${ }^{110}$ The Birmingham riots and the "Battle of the Forth" in Newcastle, both in late July, represented the climactic points in the Chartist agitations in those cities. ${ }^{111}$ In both cases, in demonstrating at first hand the power of the authorities, they fulfilled a similar role to that of the

107 Burnley magistrates to Russell, 13 August, and Clitheroe magistrates to Russell, 19 August, HO 40/37; Blackburn Standard, 14 August; Preston Chronicle, 17 August; Wigan Gazette, 16 August; Manchester Courier, 17 August.

108 R. A. Church, Economic and Social Change in a Midland Town. Victorian Nottingham 1815-1900 (London, 1966), pp. 132-35; P. Wyncoll, Nottingham Chartism (Nottingham, 1966), pp. 21-23; Macclesfield Courier, 17 August; Swanswick (from Macclesfield) to Russell, 12-14 and 17 August, HO 40/41; Assizes 65/2, examinations of Macclesfield Chartists.

109 W. H. Maehl, Jr, "Chartist Disturbances in Northeastern England, 1839", in: International Review of Social History, VIII (1963), pp. 404-13; D. J. Rowe, "Some Aspects of Chartism on Tyneside”, ibid., XVI (1971), pp. 30-36; Northern Liberator, 17 August; Carlisle Mayor to Russell, 14 and 15 August, HO 40/41; Carlisle Journal, 17 August; Carlisle Patriot, 17 August; Whitehaven Herald, 17 August.

110 Napier to Phillipps, 12 and 15 August, HO 40/53; J. L. Baxter, "Early Chartism and Labour Class Struggle: South Yorkshire, 1837-1840", in: Essays in the Economic and Social History of South Yorkshire, ed. by S. Pollard and C. Holmes (Barnsley, 1976), p. 142; F. J. Kaijage, "Labouring Barnsley, 1816-1856" (unpublished Ph.D., Warwick, 1975), pp. 495-96.

111 T. R. Tholfsen, "The Chartist Crisis in Birmingham", in: International Review of Social History, III (1958), pp. 468-72; Maehl, "The Dynamics of Violence", loc. cit., pp. 112-13, 118. 
National Holiday in the cotton district. Both cities were quiet on 12 August, as were Scotland and London. ${ }^{12}$

Yet if the physical events of the National Holiday were often not of great importance, the sense of debacle was universal. The only ulterior measure, on which serious hopes had been placed, had collapsed in confusion. General Napier wrote:

August 19th. - Everywhere a sudden calm has succeeded the storm; it is unnatural, for the causes of discontent still exist. The fact is that the Chartist leaders' calculations are quite at fault; they have found the difficulty of uniting the people in simultaneous efforts.

Everywhere, he noted, September was a month of "unvarying quietude". ${ }^{113}$ As Lowered noted, from the time the Convention abdicated responsibility over the Sacred Month "its prestige was gone". ${ }^{114}$ The National Holiday was seen as the last resort of the open campaign. When it collapsed in confusion, it signified the end of the constitutional phase of the first Chartist campaign. The conspiratorial phase was to follow.

\section{The aftermath}

In the cotton district the atmosphere had changed drastically by late August. At Leigh, Heywood, Bolton and Manchester substantial quantities of pikes were found abandoned. ${ }^{115}$ The Chartist leadership continued to be decimated by further arrests, victimisation, emigration and debilitating quarrels. ${ }^{16}$ There were no more large open-air meetings and speeches were rarely remotely violent. A Bolton report made a virtue of necessity when it claimed a "calm" and "rational" spirit had "supplanted the more noisy and declamatory agitation of a former period". At Stockport Richard Pilling, himself out on bail, noted meetings were not as "spirited" as before. ${ }^{117}$ Indeed much of the language was downright defeatist. For instance, Matthew Fletcher now believed their plans must have been

${ }_{112}$ Northern Liberator, 17 August; Thorn (from Birmingham) to Home Office, 12, 14 and 15 August, HO 40/53; A. Wilson, The Chartist Movement in Scotland (Manchester, 1970), pp. 82-83; D. Goodway, London Chartism 1838-1848 (Cambridge, 1982), p. 33. 113 Napier, General Sir Charles James Napier, II, pp. 73, 77.

114 Robert Lowery, p. 144.

115 Bolton Free Press, 24 and 31 August, 14 December; Manchester Guardian, 21 September; Manchester and Salford Advertiser, 16 November; Smith to Russell, 5 September.

${ }^{116}$ Bury Chartism was left virtually leaderless when John Rawson, the secretary, emigrated, and Matthew Fletcher (backed by the local committee) quarrelled with O'Connor and withdrew from political agitation. Manchester Guardian, 9 October; Northern Star, 21 and 28 September, 5, 12 and 19 October, 9 November.

117 Northern Star, 16 and 30 November. 
"wrong", and that "they had been attempting something which they had not either the strength or the wisdom to enable them to effect." 118

Against this background it comes as no surprise that Lancashire played very little part in the various conspiratorial schemes of the winter of 1839$40 .{ }^{119}$ It was indeed a general phenomenon of the radical campaigns of the first half of the nineteenth century that, as a result of the prior adherence to the constitutional framework, the subsequently more aggressive conspiracies were launched against an unhelpful background of defeat, recrimination and a loss of popular confidence. It was noticeable that the two areas most heavily involved in the risings of the winter of 1839-40, South Wales and Yorkshire, were the two militant areas which had largely escaped violent confrontations earlier in the campaign. It seems probable that some leaders in the cotton district knew about the Monmouth rising in advance, ${ }^{120}$ but there was no action in Lancashire. The Manchester committee was being spied upon, and verbatim reports of private meetings confirm the police assessment that they were characterised by "despair and mutual distrust". ${ }^{21}$ Possibly something was planned in Bolton at the time of the Yorkshire risings in January 1840 , but again nothing actually happened. ${ }^{122}$ No link with Lancashire was discovered by the Government investigations, and the local military commander was confident that Lancashire Chartism had lost its basis of mass support. ${ }^{123}$

Overall it does seem that there were decided parallels between the events of 1839-40 and 1819-20. For then also Lancashire had been unsurpassed in the scale of its constitutional platform agitation, the campaign had been disrupted in August by the even more dramatic event of Peterloo, and then faded as Yorkshire took the lead in conspiratorial plans. Certainly Lancashire in 1839 , as indeed in 1819 and 1848 , illustrated clearly many of the

118 Manchester and Salford Advertiser, 28 September.

119 No evidence of any actual preparations for a rising in the cotton district is presented in the two best studies of these events: A. J. Peacock, Bradford Chartism, 1838-1840 (York, 1969), and Epstein, The Lion of Freedom, ch. 5.

120 Frost, who led the Monmouth rising, was in Manchester shortly beforehand, according to a reference in Northern Star, 19 October. For assertions that the Manchester and Hyde Chartists knew in advance see Manchester Guardian, 11 December; Wemyss to Phillipps, 20 November, HO 40/43.

121 Shaw to Phillipps, 17 and 18 December, HO 40/43.

122 The local police believed there was a conspiracy, and possibly more significantly so did two usually well-informed and important moderates in the local radical movement, George Condy, editor of the Advertiser, and Abel Heywood, the principal radical bookseller and newsagent in Manchester. They both tried to forestall any rising, see Manchester and Salford Advertiser, 25 January 1840; Bolton Free Press, 25 January 1840; Shaw to Phillipps, 20 May 1840, HO 44/35.

123 Wemyss to Phillipps, 22 December, HO $40 / 40$. 
inherent flaws in the central radical tactic of threatening, mass-platform agitation. It encouraged a neglect of organisation, produced enormous problems of co-ordination and control, tended to scare off potential allies, attracted the Government repression against which radical tactical thinking had provided no real answer, and ultimately depended upon the creation of a quite unrealistic and unattainable degree of national unanimity.

However, it should be emphasised that, irrespective of the failings of the Chartist movement, the possibilities for a successful insurrection in 1839 were very slim indeed. Some of the basic reasons have been mentioned by Dorothy Thompson, the support for the Government by the upper and middle classes, the loyalty of the army and the lack of a serious foreign threat (with even Ireland able to spare troops). ${ }^{124}$ Also important was the distance between the seat of Government in London and the main storm centres. Nevertheless the lack of a national situation conducive to a successful insurrection should not be allowed to obscure the reality of the extremely widespread disaffection, and what amounted to revolutionary intent amongst the working classes in the cotton district. Yet, for whatever reason, the first Chartist campaign had obviously failed, and much of the history of the movement in the next three years can be seen as an attempt to learn from the mistakes of that campaign.

From 1840 to 1842 there was a continued emphasis upon the importance of solid organisation, in place of reliance on the vagaries of the crowds drawn by the excitement of the platform. The second great campaign of 1842 was very different from that of 1839 . The Convention was a deliberately limited affair, and there were virtually no speeches in the violent mould of 1839 . An appeal was made to obtain not only trade-union help, but also to gain lower-middle-class allies. However, everything was interrupted by the general strike of the summer of $1842 .{ }^{125}$ In the cotton district that became, for a short period, a predominantly political strike for the Charter. The events of 1839 had revealed the enormous difficulties of organising a political strike when the authorities had prior warning. The element of surprise in 1842 allowed an extensive strike to be established in the cotton district. But the subsequent leadership confusion and vacillation, and the slow and patchy national response to Lancashire's lead, revealed the insuperable problems of co-ordination and control, which were an inevitable concomitant of the surprise element. Furthermore it became clear that fundamental changes in tactical thinking had not taken place. The Manchester conference of trades, which called for a general

124 Thompson, The Early Chartists, p. 26.

125 For a full account see Sykes, "Popular Politics and Trade Unionism", ch. 15. 
strike for the Charter, remained convinced of the need to secure complete national support. It was anxious to consult with the "middle classes generally" (who were in fact increasingly repelled by the phenomenon of working-class direct action), to see "how far they are prepared to assist and support the people in the struggle". Furthermore it envisaged a general strike being established "legally and constitutionally", and was left tactically confused when resistance by the authorities produced serious violence. ${ }^{126}$ Again enormous, but localised support was sacrificed in the attempt to secure an unrealistic, and frankly unattainable degree of national unity. In 1848 Chartism returned to the more familiar constitutional pattern of 1819 and 1839 , and many mistakes were repeated. After 1848 the blatant tactical bankruptcy of the movement was a very important factor in the subsequent demise of Chartism. 